\title{
Corporate Governance and Executive Compensation for Corporate Social Responsibility
}

\section{Citation}

Hong, Bryan, Zhichuan (Frank) Li, and Dylan B. Minor. "Corporate Governance and Executive Compensation for Corporate Social Responsibility." Harvard Business School Working Paper, No. 16-014, August 2015.

\section{Permanent link}

http://nrs.harvard.edu/urn-3:HUL.InstRepos:19052357

\section{Terms of Use}

This article was downloaded from Harvard University's DASH repository, and is made available under the terms and conditions applicable to Other Posted Material, as set forth at http:// nrs.harvard.edu/urn-3:HUL.InstRepos:dash.current.terms-of-use\#LAA

\section{Share Your Story}

The Harvard community has made this article openly available.

Please share how this access benefits you. Submit a story.

Accessibility 


\section{Corporate Governance and Executive Compensation for Corporate Social Responsibility}

Bryan Hong

Zhichuan (Frank) Li

Dylan Minor

Working Paper 16-014 


\title{
Corporate Governance and Executive Compensation for Corporate Social Responsibility
}

\author{
Bryan Hong \\ Ivey Business School \\ Zhichuan (Frank) Li \\ Ivey Business School \\ Dylan Minor \\ Harvard Business School
}

Working Paper 16-014 


\title{
Corporate Governance and Executive Compensation for Corporate Social Responsibility
}

\author{
Bryan Hong \\ Ivey Business School \\ University of Western Ontario \\ bhong@ivey.ca \\ Zhichuan (Frank) Li \\ Ivey Business School \\ University of Western Ontario \\ fli@ivey.ca \\ Dylan Minor \\ Harvard Business School \\ Harvard University \\ dminor@hbs.edu
}

August 2015 


\title{
Corporate Governance and Executive Compensation for Corporate Social Responsibility
}

\begin{abstract}
We link the corporate governance literature in financial economics to the agency cost perspective of Corporate Social Responsibility (CSR) to derive theoretical predictions about the relationship between corporate governance and the existence of executive compensation incentives for CSR. We test our predictions using novel executive compensation contract data, and find that firms with more shareholder-friendly corporate governance are more likely to provide compensation to executives linked to firm social performance outcomes. Also, providing executives with direct incentives for CSR is an effective tool to increase firm social performance. The findings provide evidence identifying corporate governance as a determinant of managerial incentives for social performance, and suggest that CSR activities are more likely to be beneficial to shareholders, as opposed to an agency cost.
\end{abstract}

Keywords: Corporate governance, corporate social responsibility, incentives for CSR, executive compensation, non-financial performance measures, agency costs, board independence, institutional holdings, managerial power 


\section{Introduction}

Over the last several decades, Corporate Social Responsibility (CSR) activities have become an increasingly important investment by firms. ${ }^{1}$ The growing significance of CSR as a phenomenon has raised a fundamental question: Does CSR enhance shareholder value, or is it an agency cost enjoyed by a firm's managers at the expense of stockholders? While a substantial number of studies have examined this question from different perspectives, the evidence continues to be conflicting (Griffin and Mahon, 1997; Margolis et al., 2009; Borghesi et al., 2014; Kruger, 2014; Masulis and Reza, 2014). In this study, we investigate the agency cost perspective of CSR using a novel empirical test that exploits variation in corporate governance across firms to predict the existence of executive compensation contracts linked directly to CSR activities. Our findings suggest that corporate governance is an important mechanism determining whether managers receive compensation linked to firm social performance outcomes, and that executive compensation for CSR leads to more CSR activities. To the best of our knowledge, our study provides the first quantitative empirical evidence identifying factors that lead to executive compensation for CSR.

In the debate among scholars about the effects of CSR on firm financial performance, one of the most prominent arguments against the financial benefits of CSR has been the agency cost prediction first made by Friedman (1970), who characterized CSR activities as self-interested behavior by individual managers at the expense of the firm's shareholders. ${ }^{2}$ Subsequent studies have found supporting evidence of CSR as a potential agency cost, finding that CSR may be used to advance personal interests over the interests of shareholders (Brown et al., 2006; Jiraporn and Chintrakarn, 2013; Borghesi et al., 2014; Cheng et al., 2014; Kruger, 2014; Masulis and Reza, 2014), provide added job security to inefficient managers by pleasing stakeholders (Cespa and Cestone, 2007), compensate for the negative consequences of engaging in earnings management (Prior et al., 2008), and enhance individual reputations of managers (Barnea and Rubin, 2010). However, a number of studies have also found a positive relationship between CSR activities and

\footnotetext{
${ }^{1}$ For example, some 63\% of CEOs surveyed in the UN Global Compact-Accenture CEO Study on Sustainability (2013) expected sustainability to transform their industry within five years.

2 McWilliams et al. (2006) and Gao and Bansal (2012) provide overviews of the major theoretical perspectives regarding CSR and financial performance. In this study, however, we focus only on the agency cost argument.
} 
firm financial performance (Orlitsky et al., 2003). Despite the considerable amount of academic attention, few definitive conclusions can be drawn from the collection of findings produced thus far.

In addition to the conflicting academic evidence, anecdotal evidence from firms with strong public commitments to CSR can also provide ambiguous conclusions. For example, consider the outdoor clothing company Patagonia, which donates $1 \%$ of its revenues to environmental organizations. In a case study by Casadesus-Masanell et al. (2009, p.209), a former senior manager at the company provides potentially conflicting views of the financial benefits of CSR, stating both that they seek to "dispel the myth that in order to have a high quality product you have to have something damaging to the environment," and then later stating "There is some tension between the environment and product quality...the reality is that they don't always go hand in hand." These seemingly opposing statements raise more questions than answers in addressing whether CSR is truly beneficial for firm financial performance, or a net cost to the firm's shareholders.

With respect to agency costs, a fundamental premise of the corporate governance literature within the field of financial economics is the notion that improved corporate governance ultimately leads to improved firm financial performance and value created for shareholders through the adoption of shareholder-friendly policies and the reduction of agency costs (Gompers, Ishii, and Metrick, 2003, 2010). More shareholder-friendly (better) corporate governance is achieved through the implementation of rules, practices, and incentives to align the interests of a firm's managers with shareholders. As a consequence, shareholders benefit economically by advocating for improved corporate governance.

In this paper, we link the corporate governance literature in financial economics and the agency cost perspective of CSR to derive theoretical predictions about the relationship between corporate governance and the existence of executive compensation contracts that provide incentives for firm social performance. The underlying theoretical logic of our test is a straightforward extension of the agency cost perspective: If CSR is truly an agency cost at the expense of a firm's shareholders, then firms with better corporate governance should be less likely to compensate their managers for CSR outcomes. If, however, CSR increases shareholder value, better corporate governance should predict a higher likelihood of observing executive compensation contracts that provide incentives for firm social performance. Given that the 
structure of executive compensation contracts is a direct outcome of a firm's governance process (e.g., Yermack, 1997; Core, Holthausen, and Larcker, 1999; Bebchuk and Fried, 2004), we are able to infer whether CSR activities are truly agency costs, or beneficial for firm financial performance.

The relationship between corporate governance and CSR activities within firms has received increasing attention among scholars, motivated by the potentially important role of governance in influencing socially responsible firm behavior (see Walls et al., 2012 for a review). However, the literature has thus far produced contradictory results, finding evidence of negative (Coombs and Gilley, 2005; David et al., 2007), insignificant (Graves and Waddock, 1994; Schnatterly 2003), and positive (Coffey and Fryxell, 1991; Jo and Harjoto, 2011; Oh et al., 2011; Rupley et al., 2012) relationships between corporate governance and CSR. We argue one possible reason for the inconsistency in previous findings may be the lack of empirical measures at the individual manager level of the channels through which corporate governance may influence CSR. Given that the purpose of corporate governance is to influence managerial decision-making (Zeckhauser and Pound, 1990), the effects of governance on firm social performance are likely to occur through its influence on individual managers. A more detailed examination of these channels may be necessary in order to better understand the nature of the relationship between corporate governance and CSR.

Similarly, a nascent literature has examined the effect of executive compensation on CSR, but has also found conflicting results (Mahoney and Thorn, 2006). McGuire et al. (2003) find no significant relationship between incentives and firm social performance, while Deckop et al. (2006), Berrone and Gomez-Mejia (2009a), and Mahoney and Thorn (2005) find evidence of a positive relationship. However, as Berrone and Gomez-Mejia (2008) note, too few studies have been conducted thus far to reach any clear conclusions. Also, while prior studies have examined the relationship between executive compensation structure and CSR, no quantitative empirical study has yet examined the role of executive compensation contracts that explicitly incentivize managers for firm social performance.

We conduct our empirical test on hand-collected compensation contract data for the top five highest paid executives of firms in the Standard and Poor's 500 Index in 2013, linked to corporate governance measures commonly used in the financial economics literature. The results provide 
consistent evidence that better corporate governance predicts a greater likelihood of observing executive compensation contracts with incentives linked to CSR outcomes. A one standard deviation increase in the percentage of the board of directors hired prior to a CEO's arrival predicts a $13 \%$ increase in the odds of compensation for CSR, while the incremental addition of a large institutional (block) shareholder is associated with an 8\% increase in the odds of observing CSR incentives. ${ }^{3}$ We also find that when managers have greater individual power within the firm and governance is less shareholder-friendly (weaker), they are less likely to have executive compensation contracts tied to CSR outcomes. A one standard deviation increase in the shares outstanding owned by an executive predicts an $8 \%$ decline in the odds of observing incentives linked to CSR, and the odds decline 19\% if the executive is also a member of the board of directors. Taken together, the results provide evidence against the notion of CSR as an agency cost at the expense of shareholders, and suggest that CSR activities are likely to provide at least some form of economic benefit for firms. In addition, we find a positive relationship between the presence of explicit incentive compensation for CSR and actual firm-level CSR activities.

Our paper makes five main contributions. First, our findings establish explicit compensation for CSR as one important channel through which corporate governance may influence CSR outcomes, identifying a clear mechanism through which corporate governance may influence firm social performance. Second, by being the first to directly measure CSR contracting, we are able to demonstrate a clear positive relationship between a component of executive compensation structure (incentives for CSR) and firm social performance, contributing to the growing literature examining how executive compensation and CSR activities might be related. Third, we contribute more broadly to the literature examining executive compensation for non-financial performance measures, which finds that including incentives for value-relevant performance measures beyond purely financial performance metrics can improve managerial incentives (Chen et al., 2014; Davila and Venkatachalam, 2004; Ibrahim and Lloyd, 2011; Ittner et al., 1997; Schiehll and Bellavance, 2009). Our results suggest that CSR is a non-financial performance measure that contains valuerelevant information, and that corporate boards may implement CSR-linked incentives in order to increase shareholder value. Fourth, to our knowledge, our results provide the first empirical evidence of factors that predict the existence of compensation incentives linked to social

\footnotetext{
${ }^{3}$ All associations mentioned here are from Tables 4 and 5 , with the odds ratio computed using the exponential function of the coefficients.
} 
performance outcomes. Surprisingly, although almost $40 \%$ of the executives in our sample have compensation contracts that contain explicit incentives directly linked to CSR, little is known about the conditions under which such contracts are more or less likely to exist (Berrone and Gomez-Mejia, 2009b). Our findings provide evidence of the role of corporate governance as one mechanism that may predict the emergence of such social performance-based incentives. Finally, our results provide clear supporting evidence of CSR as important for increasing shareholder value, complementing a number of studies that find a positive relationship between CSR and firm financial performance, and contrary to the agency cost prediction.

The remainder of this paper is organized as follows. In Section 2, we develop our hypotheses linking corporate governance and executive compensation contracts tied to CSR. In Section 3, we describe our data and measures, and our empirical analysis. In Section 4, we present and discuss the empirical results. In Section 5, we offer conclusions.

\section{Hypotheses}

Corporate governance is concerned with the mechanisms through which shareholders ensure a financial return on their investments (Shleifer and Vishny, 1997). The fundamental dilemma of corporate governance is the imperfect alignment of incentives between shareholders and managers, which can lead to behaviors and decisions by managers that are not in the interests of the firm's shareholders (Roe, 1994). ${ }^{4}$ When managers act in their own personal interest at the expense of shareholders, this results in agency costs for the firm's owners, reducing the level of shareholder value (Jensen and Meckling, 1976). To assuage this cost, shareholders can use managerial incentives to help align the manager's interests with those of shareholders.

The degree of agency cost within a particular firm is then determined by the balance of control between (independent) shareholders and managers---the strength of the corporate governance of the firm. As the balance of control increasingly favors shareholders, incentives are put in place such that managers are more likely to engage in shareholder-maximizing activities.

\footnotetext{
4 This does not assume that all managers always act in a way opposed to shareholders. Instead, some managers sometimes act in such a way. When analyzing the data, this then results in an average agency cost.
} 
By contrast, as managers have more control, they have greater discretion to engage in shareholdercostly activities.

First, we use average director tenure of the board (AVG TENURE) to proxy for board independence. Social network theory suggests that board members develop and solidify their friendship or social ties with management as their tenure on the board increases, making them less independent (e.g., Boeker and Goodstein, 1993; Wade et al., 1990; Vafeas, 2003; Harris and Helfat, 2007). Activists and governing institutions such as the NACD (1996), CII (1998), and U.S. Senate (2002) believe that longer service on the board does not bode well for monitoring management and as such, suggest tenure limits as a policy prescription. ${ }^{5}$

However, director tenure as a proxy for board independence could be ambiguous. An alternative theory suggests a potential benefit of longer board service. The managerial talent paradigm posits that directors accumulate considerable experience and skill as their tenure on the board increases (Buchanan, 1974; Salancik, 1977; Vance, 1983). Such directors are more confident and powerful, and more likely to challenge management when necessary.

Therefore, following Harjoto, Laksmana, and Lee (2014) and Coles, Daniel, Naveen (2014), we use another measure of board independence, the percentage of board members hired before the CEO (\% HIREBEFORE), which we argue is less ambiguous. If a board member is hired after the CEO, they are more likely to be "sympathetic" because the CEO often exerts considerable influence in the board nomination process (Finkelstein and Hambrick, 1989; Hwang and Kim, 2009). In this paper, we use both AVG TENURE and \% HIREBEFORE to measure board independence.

When considering executive compensation contracts, if CSR activities are an agency cost, ${ }^{6}$ contractual incentives for CSR should be less likely to exist when the firm's board of directors has greater independence. However, if CSR activities maximize shareholder value, greater board

\footnotetext{
${ }^{5}$ As a robustness check, we also used the fraction of the board that is composed of independent directors (Rosenstein and Wyatt, 1990) as a proxy for board independence, and find consistent results. The caveat of this proxy is that most S\&P 500 firms have fairly "independent" boards.

${ }^{6}$ CSR activities that benefit the manager at the expense of the firm represent an agency cost. For example, if a CEO uses firm resources to advance a charitable cause that represents a self-serving interest of the CEO but that does not benefit the firm, it may be costly to the firm.
} 
independence should predict a greater likelihood of incentives explicitly tied to CSR. We present these two competing hypotheses formally here:

H1a: If CSR maximizes shareholder value, board independence makes it more likely that a firm contracts on CSR.

H1b: If CSR is an agency cost, board independence makes it less likely that that a firm contracts on CSR.

In addition to board composition, shareholders themselves may serve as an important enforcement mechanism to reduce agency costs. Large institutional shareholders, by virtue of their significant ownership in firms, have both the incentives and power to monitor the decisions and activities of a firm's managers (Shleifer and Vishny, 1986). Consistent with this hypothesis, institutional shareholders have been found to play an important role in preventing the enactment of amendments harmful to shareholders (Jarrell and Poulsen, 1988; Brickley, Lease, and Smith, 1988), improving compensation practices by linking pay more directly with performance outcomes (Hartzell and Starks, 2003; Matsumura and Shin, 2005), and enhancing firm value as measured by Tobin's Q (McConnell and Servaes, 1990). As a result, the presence of large institutional shareholders suggests that agency costs should be reduced within firms, leading to a testable set of competing hypotheses about their relationship with the presence of incentives for CSR in executive compensation contracts.

H2a: If CSR maximizes shareholder value, the likelihood of contracting on CSR is increasing in the number of large institutional shareholders.

H2b: If CSR is an agency cost, the likelihood of contracting on CSR is decreasing in the number of large institutional shareholders.

In contrast to strong corporate governance, increased managerial power means boards do not always bargain at arm's length because of management's influence over them. Sometimes managerial power is excessive compared to the efficient level suggested by optimal contracts (e.g., Bertrand and Mullainathan, 1999; Bebchuk, Fried, and Walker, 2002). When managers have excessive power and become "entrenched", agency costs are much more likely to occur at the expense of shareholders (e.g., Shleifer and Vishny, 1989; Bebchuk, Fried, and Walker, 2002). Possessing higher degrees of managerial power also allows managers to have greater influence over how they are compensated, leading to overcompensation of managers through contract terms 
that are less transparent or more difficult to value (Bebchuk and Fried, 2004). Consequently, managers with greater influence over the structure of their compensation contracts will be more likely to have incentives for CSR if social performance activities represent an agency cost. For example, if CSR outcomes are more difficult to measure, CSR-based compensation may be a means by which some managers can more easily extract additional compensation. Alternatively, if CSR is not an agency cost, greater managerial power should predict fewer CSR-based contracts.

To measure managerial power, we begin by considering the percentage of shares outstanding owned by individual executives at a firm, following previous studies in the financial economics literature considering the effects of managerial power on firm outcomes (e.g., Davila and Venkatachalam, 2004; Moeller, 2005; Linck, Netter, and Yang, 2008). As the percentage of shares owned by an individual manager increases, the effectiveness of corporate governance mechanisms regulating their decisions becomes weaker, leading to greater influence on their part in determining the structure of their compensation contracts. We integrate the notion of managerial power with the perspective of CSR as an agency cost versus a shareholder value-enhancing activity with the following competing predictions:

H3a: If CSR maximizes shareholder value, the likelihood of contracting on CSR is decreasing in the level of top-manager ownership.

H3b: If CSR is an agency cost, the likelihood of contracting on CSR is increasing in the level of top-manager ownership.

As an additional measure of managerial power, we consider instances where executives are also members of a firm's board of directors. In contrast to the percentage of board members who are independent of the firm, overlapping membership between the top management team and a firm's board of directors can diminish the strength of a firm's corporate governance in regulating the decisions of managers, since managers who are board members can directly influence the board's decision making process, including their compensation (e.g., Finkelstein and Hambrick, 1988; Bebchuk, Cremers, and Peyer, 2011). We consider this additional measure of managerial power here:

H4a: If CSR maximizes shareholder value, the likelihood of contracting on CSR is reduced when the manager is also a director. 
H4b: If CSR is an agency cost, the likelihood of contracting on CSR is increased when the manager is also a director.

A necessary condition for the previous hypotheses to be valid is that providing incentives to managers to engage in CSR actually generates higher levels of CSR within firms, suggesting that the incentive should be effective in increasing the level of CSR engagement by firms. If instead incentive contracts tied to CSR did not result in greater social performance, then stronger corporate governance is unlikely to predict a higher likelihood of observing executive compensation contracts linked to CSR. Ultimately, CSR must provide sufficient returns for firm financial performance in order to be worth investing in, and executive compensation contracts providing incentives for CSR must lead to actual improved social performance within firms. Our final hypothesis captures this necessary condition:

H5: If CSR maximizes shareholder value, contracting on CSR is associated with an increase in firm CSR.

\section{Data and Measures}

To test our hypotheses, we consider the sample of top five executives working at each firm in the Standard and Poor's 500 Index disclosed in public company filings to the Securities and Exchange Commission (SEC). ${ }^{7}$ To conduct our analysis, we link relevant data from multiple sources. We begin by considering the universe of top managers available in the Execucomp database provided by S\&P Capital IQ, and examine those executives working at firms comprising the S\&P 500 index in 2012. All data from other sources are for the year 2012, except for CSR compensation contract data, which is for the year 2013. By lagging the independent variables by one year, we estimate how corporate governance predicts the subsequent existence of incentives for CSR. Execucomp includes a variety of personal information disclosed in public company

\footnotetext{
${ }^{7}$ The data has selection bias towards large public firms, although S\&P 500 firms are used widely in related areas, including many influential studies such as Hart and Ahuja (1996) and Stanny (2013) on emission reduction; Hall and Liebman (1997) on CEO compensation; Anderson and Reeb (2003) on family ownership. Walls, Berrone, and Phan (2012) also used only S\&P 500 firms to study the relationship between corporate governance and environmental performance.
} 
filings for the top five executives at each firm. For our measure of CSR, we use data provided by Kinder, Lydenberg, and Domini (KLD), a third-party data vendor that provides CSR ratings for publicly traded firms. KLD ratings are among the most influential and widely studied measures of CSR used in prior literature (Berman et al., 1999; Chatterji et al., 2009; Flammer and Kacperczyk, 2015; Servaes and Tamayo, 2013; and Werner, 2014). Financial statement data are from Compustat, and data on board independence is from the Investor Responsibility Research Center‘s (IRRC) governance and director database. We obtain institutional ownership data from Thomson Financial, consisting of 13F filings reported to the Securities and Exchange Commission.

To obtain data on executive compensation contracts tied to CSR, we manually collected relevant compensation data from 2014 Proxy Statements, which describe 2013 compensation activities, for each firm where our sample of executives is employed. Specifically, in the Compensation Discussion and Analysis section, sources of variable pay and performance-based pay are identified. If compensation is based on non-financial performance and related to CSR activities (see Appendix 2 for a detailed description), an executive is coded as having incentives linked to CSR, and her firm is coded as offering CSR incentives. In addition, each company's most recent annual report and corporate social responsibility report were reviewed for any additional details, although these latter sources were not used to identify the existence of compensation linked to CSR. By following this approach, only firms that formally disclosed CSR-linked incentives to regulators and investors were recorded as providing compensation linked to CSR. For our analysis, we create a dummy variable equal to one (variable CSRCONTRACTING) if an executive's compensation contract contains incentives linked to CSR. After excluding any observations without KLD, Compustat, and Execucomp data, the full sample consists of 2,561 executive-level observations. Some specifications had fewer observations due to one or more missing data values.

To measure the degree of independence the firm's board of directors has from management, we calculate the average director tenure of the board (AVG TENURE), following previous studies (e.g., Vafeas, 2003; Harris and Helfat, 2007). Following Harjoto, Laksmana, and Lee (2014) and Coles, Daniel, Naveen (2014), we use an additional measure of board independence, the percentage of board members hired before the CEO’s hire (\% HIREBEFORE).

Following Ashbaugh-Skaife, Collins, and LaFond (2006), we measure the number of large institutional shareholders by calculating the number of block shareholders (NUMBLOCKS), 
where a block shareholder is defined as an institution that owns more than $5 \%$ of a firm's outstanding voting shares. Jensen (1993) and Shleifer and Vishny (1997) argue that block shareholders that hold large equity positions in a company are important to a well-functioning governance system because they have the financial interest and independence to evaluate firm management and policies in an unbiased manner, and have the voting power to pressure management to make changes if they observe agency cost behavior. Consistent with this view, Gordon and Pound (1993) find that the structure of share ownership significantly influences voting outcomes on shareholder-sponsored proposals to change corporate governance structures. Block shareholders have also been found to improve financial performance through their efforts to improve corporate governance. For example, Nesbitt (1994) finds that firms targeted by the California Public Employees’ Retirement System (CalPERS) experience positive long-run stock returns, and Opler and Sokobin (1997) find that firms experience above-market performance the year after being targeted by the Council of Institutional Investors. These results suggest that active institutional shareholders lead to more efficient monitoring of management and less agency cost behavior.

For our measures of managerial power, we follow prior empirical studies in the financial economics literature examining executive compensation to create two distinct variables. For our first measure, we calculate the percentage of shares outstanding owned by executives at a firm (e.g., Davila and Venkatachalam, 2004; Moeller, 2005; Linck, Netter, and Yang, 2008). For our second measure, we create a dummy variable equal to one if an executive is also a member of the firm's board of directors (e.g., Finkelstein and Hambrick, 1988; Bebchuk, Cremers, and Peyer, 2011). Both of these variables, SHROWN and EXECDIR, are constructed based on Execucomp data.

Controlling for the level of firm social performance is necessary in our analysis, because it may be that firms with better corporate governance also engage in more CSR activities, leading to potential omitted variable bias in our regressions and incorrect inferences. To measure the level of CSR activities by firms, we calculate the total number of KLD strengths minus concerns over a set of categories measuring CSR (variable CSRLEVEL), following the convention used by previous empirical studies (Griffin and Mahon, 1997; Waddock and Graves, 1997; Johnson and Greening, 1999; Mishra and Suar, 2010). We exclude industry-specific categories and the corporate 
governance category, and consider the KLD categories of community, diversity, employee relations, environment, human rights, and product in our measure.

We also include several other control variables, commonly used in the CSR and executive compensation literature, in our analysis. To control for differences between the Chief Executive Officer role and other executives in our sample that might affect the probability of observing compensation contracts linked to CSR outcomes, we include a dummy variable equal to one if the executive is the Chief Executive Officer (variable CEO). Following previous studies, we control for the two most widely established determinants of executive compensation: firm size and financial performance (Berrone and Gomez-Mejia, 2009). We use (ROA) for the latter and logged sales for the former (Mahoney and Thorne, 2005; Deckop, Merriman, and Gupta, 2006). In addition to these important factors, we follow Jo and Harjoto (2012) and control for leverage (BOOKLEVERAGE), R\&D intensity (R\&D), advertising intensity (AD), and industry by including dummies for each Fama-French 48 industry classification (FF48 Industry). Appendix 1 provides a more detailed description of each variable used.

Table 1 presents summary statistics on the incentives for the top executives in our sample, executive characteristics, firm characteristics, and investment and financing measures.

\section{Results and Discussion}

\section{Univariate Tests}

To examine potential differences between firms with compensation contracts linked to CSR and those without contracts, we compare both types of firms in Table 2. In general, CSR contracting is more common in larger firms with more independent boards, less insider ownership, lower financial performance (measured by ROA), higher social performance (measured by KLD scores), and lower advertising intensity. More independent boards, less insider ownership, and fewer executives who are also board members in CSR-contracting firms are consistent with our hypotheses that CSR is likely to be financially beneficial to firms (H1a, H3a, H4a). By contrast, the negative correlation between the number of block shareholders and the presence of 
compensation for CSR is consistent with CSR being a wasteful activity borne as an agency cost (H2b). However, we note that these correlations are not adjusted for industry and do not account for the correlation of our independent variables of interest with our other control variables. Table 3 reports the correlations between all the key variables. As a next step, we conduct multivariate tests to address these potential issues.

\section{Multivariate Tests}

Table 4 reports the results testing H1 and H2. In both cases, we find supporting evidence for hypotheses H1a and H2a. In particular, average director tenure is negatively related to the existence of CSR incentives (Column 2), while the percentage of board members hired prior to the CEO's arrival and the number of institutional block shareholders are positively associated with the presence of CSR compensation contracts (Columns 4 and 6, respectively). In terms of magnitude, a one year increase in average director tenure is associated with 7\% lower odds of observing CSR incentives, a one standard deviation increase in the percentage of the board hired prior to the CEO's arrival is associated with $13 \%$ higher odds of CSR contracting, and the presence of one additional institutional block shareholder is associated with $8 \%$ higher odds of observing CSR compensation. Taken together, the results suggest firms with better corporate governance are substantially more likely to provide compensation contracts linked to CSR.

Examining the potential influence of greater managerial power, Table 5 reports results that support hypotheses H3a and H4a. The coefficient estimate on the fraction of shares owned by the individual executive is negative and significant at the $1 \%$ level for all specifications (Columns 1 , 2 and 6). The estimate from Column 2 suggests that a one standard deviation increase in executive share ownership results in an 8\% decrease in the odds of CSR contracting. The coefficient estimate for the dummy variable of whether or not the executive is also a board member (i.e., EXECDIR) is modestly significant at the $10 \%$ level. Results in Column 4, with all controls, suggest that if an executive is also a board member, there is a $19 \%$ decrease in the odds of CSR contracting. ${ }^{8}$ However, although the magnitude is similar when including the fraction of executive shares owned in the same specification (Column 6), the coefficient estimate is no longer significant.

\footnotetext{
${ }^{8}$ Considering almost all the CEOs are board members, we test the hypotheses in the non-CEO sample and found similar results to support our hypotheses.
} 
Taken together, the coefficient estimates for all four of our hypotheses provide consistent evidence that both improved corporate governance and reduced managerial power predicts a greater likelihood of observing compensation contracts tied to social performance. Our results suggest that CSR is not a form of managerial excess or agency cost, but may be beneficial to shareholders and firm financial performance.

Finally, we test whether the existence of compensation contracts tied to CSR is associated with higher levels of CSR activities at the firm level, with results shown in Table 6. The coefficient estimate for CSRCONTRACTING is positive and significant across specifications, providing support for Hypothesis 5 and suggesting that contracting on CSR does improve firms' CSR level in the following year ${ }^{9}$, even after controlling for the firm's current level of social performance. The results suggest that providing incentives for CSR to managers may be effective in improving firm social performance.

\section{Conclusion}

We investigated the link between corporate governance and executive compensation for CSR, and extended the agency cost perspective of CSR to develop our hypotheses. If CSR provides sufficient financial returns to shareholders, firms with stronger corporate governance should incentivize their managers to invest in social performance. However, if CSR represents managerial excess and is an agency cost, then firms with better governance should be less likely to provide incentives for CSR.

In our results, we found consistent evidence that CSR is likely to be financially beneficial for firms, and for shareholders. Firms with more shareholder-friendly governance are more likely to incentivize their managers to engage in CSR. Also, firms that provided compensation linked to CSR had greater levels of social performance on average, consistent with the notion that the provision of incentives for CSR leads to more CSR activities.

\footnotetext{
${ }^{9}$ Both CSRCONTRACTING and the dependent variable CSRLEVEL are for year 2013. However, compensation contracts are usually determined at the beginning of the year or the end of previous year, while CSR levels are evaluated over the entire year.
} 
To our knowledge, our study is the first to document the prevalence of executive compensation contracts for CSR. Almost 40\% of our sample, which consists of the Standard and Poor's 500 Index, includes some form of compensation for CSR to their top managers. Our future research will extend to smaller firms and multiple periods. In addition, better understanding exactly how and when firms choose to compensate executives for CSR provides fruitful opportunities for future research. By examining the role of corporate governance and agency cost explanations of CSR, our study aims to provide a first step in this direction. 


\section{References}

Ashbaugh-Skaife, Collins, and LaFond, 2006. The effects of corporate governance on firms' credit ratings, Journal of Accounting and Economics, 42:1-2, 203-243

Barnea, A., \& Rubin, A. 2010. Corporate social responsibility as a conflict between shareholders. Journal of Business Ethics, 97(1), 71-86.

Bebchuk, Lucian, K. Martijn Cremers, and Urs Peyer, 2011. The CEO pay slice. Journal of Financial Economics, 102 (1), 199-221.

Bebchuk LA, Fried JM., 2004. Pay without Performance: The Unfulfilled Promise of Executive Compensation. Cambridge, MA: Harvard Univ. Press.

Bebchuk, Lucian Arye, Jesse M. Fried, and David I. Walker. 2002. Managerial Power and Rent Extraction in the Design of Executive Compensation. University of Chicago Law Review 69:3, pp. 751-846.

Berman, S.L., A.C. Wicks, S. Kotha, and T.M. Jones, 1999, Does stakeholder orientation matter? The relationship between stakeholder management models and firm financial performance, Academy of Management Journal 42, 488-506.

Berrone, P., \& Gomez-Mejia, L. 2008. Beyond financial performance: is there something missing in executive compensation schemes? Global Compensation: Foundations and Perspectives (Routledge, New York), 206-218.

Berrone, P., \& Gomez-Mejia, L. R. 2009a. Environmental performance and executive compensation: An integrated agency-institutional perspective. Academy of Management Journal, 52(1), 103-126.

Berrone, P., and Gomez-Mejia, L. R. 2009b. The pros and cons of rewarding social responsibility at the top. Human Resource Management, 48(6), 959-971.

Boeker, Warren, and Jerry Goodstein., 1993. Performance and successor choice: The moderating effects of governance and ownership. Academy of Management Journal 36.1: 172-186.

Borghesi, R., Houston, J. F., \& Naranjo, A. 2014. Corporate socially responsible investments: CEO altruism, reputation, and shareholder interests. Journal of Corporate Finance, 26, 164-181.

Brickley, James, Ronald Lease, and Clifford Smith, 1988. Ownership structure and voting on antitakeover amendments, Journal of Financial Economics, 20, 267-291.

Brickley, J.A., Coles, J.L., and Terry, R.L., 1994. Outside directors and the adoption of poison pills. Journal of Financial Economics 35 (3), 371-390.

Brown, W. O., Helland, E., \& Smith, J. K. 2006. Corporate philanthropic practices. Journal of Corporate Finance, 12(5), 855-877. 
Buchanan, B., 1974. Building organizational commitment: the socialization of managers in work organizations. Administrative Science Quarterly. 19, 533-546.

Casadesus-Masanell, R., Crooke, M., Reinhardt, F., \& Vasishth V, 2009, Households' willingness to pay for "green” goods: evidence from Patagonia's introduction of organic cotton sportswear, Journal of Economics \& Management Strategy, 18(1), 203-233.

Cespa, G., \& Cestone, G. 2007. Corporate social responsibility and managerial entrenchment. Journal of Economics \& Management Strategy, 16(3), 741-771.

Chatterji, A.K., D.I. Levine, and M. Toffel, 2009, How well do social ratings actually measure corporate social responsibility? Journal of Economics and Management Strategy 18, 125-169.

Chen, C. X., Matsumura, E. M., Shin, J. Y., \& Wu, S. Y. C. 2014. The Effect of Competition Intensity and Competition Type on the Use of Customer Satisfaction Measures in Executive Annual Bonus Contracts. The Accounting Review, 90(1), 229-263.

Cheng, H., Hong, H., Shue, K., 2014. Do managers do good with other peoples money? Unpublished working paper. Dartmouth College - Tuck School of Business, Princeton University, and University of Chicago - Booth School of Business.

Coles, J. L., Daniel, N. D., and Naveen, L., 2014. Co-opted boards. Review of Financial Studies, 27(6), 1751-1796.

Coombs JE, Gilley KM. 2005. Stakeholder management as a predictor of CEO compensation: main effects and interactions with financial performance. Strategic Management Journal 26(9): 827-840.

Core, J. E., R. W. Holthausen, and D. F. Larcker, 1999. Corporate governance, chief executive officer compensation, and firm performance. Journal of Financial Economics 51: 371-406.

Council of Institutional Investors (CII), 1998, Core Policies, Positions and Explanatory Notes. Washington, DC.

David, P., Bloom, M., \& Hillman, A. J. 2007. Investor activism, managerial responsiveness, and corporate social performance. Strategic Management Journal, 28(1), 91-100.

Davila, A., and Venkatachalam, M. 2004. The relevance of non-financial performance measures for CEO compensation: evidence from the airline industry. Review of Accounting Studies. 9, 443464.

Dechow, P. M.; and I. D. Dichev, 2002. The quality of accruals and earnings: The role of accrual estimation errors. The Accounting Review, 77: 35-59.

Deckop, J. R., Merriman, K. K., \& Gupta, S. 2006. The effects of CEO pay structure on corporate social performance. Journal of Management, 32(3), 329-342. 
Finkelstein, Sydney and Donald C. Hambrick, 1988, Chief executive compensation: A synthesis and reconsideration, Strategic Management Journal, 9, 543-558.

Flammer, C., 2014. Does product market competition foster corporate social responsibility? Evidence from trade liberalization. Strategic Management Journal.

Flammer C, Kacperczyk AJ., 2015. The Impact of Stakeholder Orientation on Innovation: Evidence from a Natural Experiment, Management Science, forthcoming.

Friedman, M., 1970, The social responsibility of business is to increase its profits, New York Times Magazine, September 13: 32-33, 122, 124, 126.

Gao, J., and Bansal, P., 2013, Instrumental and Integrative Logics in Business Sustainability, Journal of Business Ethics, 112(2): 241 - 255.

Gompers, P., Ishii, J., and Metrick, A., 2003. Corporate governance and equity prices. Quarterly Journal of Economics, 118, 107-155.

Gompers, P., Ishii, J., and Metrick, A., 2010. Extreme governance: An analysis of dual-class firms in United States. Review of Financial Studies, 23(3), 1051-1088.

Gordon, L., and Pound, J., 1993. Information, ownership structure, and shareholder voting: evidence from shareholder-sponsored corporate governance proposal. Journal of Finance, 48, 697-718.

Griffin, J.J. and J.F. Mahon, 1997, The corporate social performance and corporate financial performance debate: Twenty-five years of incomparable research, Business and Society 36, 5-31.

Griffin, J.J. and J.F. Mahon, 1997, The corporate social performance and corporate financial performance debate: Twenty-five years of incomparable research, Business and Society 36, 5-31.

Harjoto, M., Laksmana, I., and Lee, R., 2014. Board diversity and corporate social responsibility. Journal of Business Ethics, 1-20.

Harris, D.A., Helfat, C.E., 2007. The board of directors as a social network: a new perspective. Journal of Management Inquiry. 16, 228-237.

Hartzell, J.C. and L.T. Starks, 2003. Institutional Investors and Executive Compensation, Journal of Finance, 58, 2351-2374.

Hwang B., Kim S. 2009. It pays to have friends. Journal of Financial Economics, 93:138-58.

Ibrahim, S., \& Lloyd, C. 2011. The association between non-financial performance measures in executive compensation contracts and earnings management. Journal of Accounting and Public Policy, 30(3), 256-274. 
Ittner, C. D., Larcker, D. F., \& Rajan, M. V. 1997. The choice of performance measures in annual bonus contracts. Accounting Review, 231-255.

Krueger, P. 2014. Corporate goodness and shareholder wealth. Journal of Financial Economics, Forthcoming.

Jarrell, Gregg, and Annette Poulsen, 1988, Shark repellents and stock prices: The effects of antitakeover amendments since 1980, Journal of Financial Economics, 19, 127-168.

Jensen, M., 1993. The modern industrial revolution, exit, and failure of internal control systems. Journal of Finance 48: 831-880.

Jensen, M.C. Meckling, W., 1976. Theory of the firm: Managerial behavior, agency costs and capital structure. Journal of Financial Economics 3, 305-380.

Jiraporn, P., \& Chintrakarn, P. 2013. How do powerful CEOs view corporate social responsibility (CSR)? An empirical note. Economics Letters, 119(3), 344-347.

Jo, H., \& Harjoto, M. A. 2011. Corporate governance and firm value: The impact of corporate social responsibility. Journal of Business Ethics, 103(3), 351-383.

Jo, H., and Harjoto, M., 2012. The causal effect of corporate governance on corporate social responsibility. Journal of Business Ethics, 106(1), 53-72.

Johnson, R.A. and D.W. Greening, 1999, The effects of corporate governance and institutional ownership types on corporate social performance, Academy of Management Journal 42, 564-576.

Krüger, P., 2015. Corporate goodness and shareholder wealth. Journal of financial economics, 115(2), 304-329.

Linck, J.S., J.M. Netter and T. Yang, 2008, The determinants of board structure, Journal of Financial Economics, 87, 308-328.

Mahoney, L. S., \& Thorne, L. 2005. Corporate social responsibility and long-term compensation: Evidence from Canada. Journal of Business Ethics, 57(3), 241-253.

Mahoney, L. S., \& Thorn, L. 2006. An examination of the structure of executive compensation and corporate social responsibility: A Canadian investigation. Journal of Business Ethics, 69(2), 149-162.

Margolis, J.D., H.A. Elfenbein, and J.P. Walsh, 2009, Does it pay to be good...and does it matter? A meta-analysis of the relationship between corporate social and financial performance, Working paper, Harvard University, Washington University in St. Louis, and University of Michigan.

Matsumura, E. M. and J. Y. Shin, 2005, Corporate Governance Reform and CEO Compensation: Intended and Unintended Consequences, Journal of Business Ethics. 62(2), 101-113. 
Masulis, R. W., \& Reza, S. W. 2015. Agency problems of corporate philanthropy. Review of Financial Studies, 28(2), 592-636.

McConnell, John J., and Henri Servaes, 1990, Additional evidence on equity ownership and corporate value, Journal of Financial Economics 27, 595-612.

McGuire, J., S. Dow and K. Argheyd. 2003. CEO Incentives and Corporate Social Performance', Journal of Business Ethics 45(4), 341-359.

McWilliams, A., Siegel, D. S., and Wright, P. M., 2006. Corporate social responsibility: Strategic implications*. Journal of management studies, 43(1), 1-18.

Mishra, S., and D. Suar, 2010. Does Corporate Social Responsibility Influence Firm Performance of Indian Companies? Journal of Business Ethics 95:571-601.

Moeller, T., 2005. Let's make a deal! How shareholder control impacts merger payoffs. Journal of Financial Economics. 76, 167-190.

National Association of Corporate Directors, 1996. Report of the NACD Blue Ribbon Commission on Director Professionalism.

Nesbitt, S., 1994. Long-term rewards from shareholder activism: a study of the 'CalPERS' effect. Journal of Applied Corporate Finance 6, 75-80.

Opler, T., and Sokobin, J., 1997. Does coordinated institutional shareholder activism work? An analysis of the activities of the council of institutional investors, Working Paper, Ohio State University.

Orlitzky, M., F.L. Schmidt, and S.L. Rynes, 2003, Corporate social and financial performance: a meta analysis, Organization Studies 24, 403-441.

Prior, D., Surroca, J., \& Tribó, J. A. 2008. Are socially responsible managers really ethical? Exploring the relationship between earnings management and corporate social responsibility. Corporate Governance: An International Review, 16(3), 160-177.

Roe, M. J. 1994. Strong Managers, Weak Owners: The Political Roots of American Corporate Finance. Princeton University Press, Princeton.

Rosenstein, S., and J. G. Wyatt., 1990. Outside directors, board independence, and shareholder wealth. Journal of Financial Economics 26: 175-91.

Rupley, K. H., Brown, D., \& Marshall, R. S. 2012. Governance, media and the quality of environmental disclosure. Journal of Accounting and Public Policy, 31(6), 610-640.

Ryan, Harely, E., and Roy. A. Wiggins III, 2004. Who is in whose pocket? Director compensation, board independence, and barriers to effective monitoring, Journal of Financial Economics, 73, 497-524. 
Schiehll, E., \& Bellavance, F. 2009. Boards of Directors, CEO Ownership, and the Use of NonFinancial Performance Measures in the CEO Bonus Plan. Corporate Governance: An International Review, 17(1), 90-106.

Schnatterly K. 2003. Increasing firm value through detection and prevention of white-collar crime. Strategic Management Journal 24(7): 587-614.

Shleifer, A., and Vishny, R. W., 1986. Large shareholders and corporate control. The Journal of Political Economy, 461-488.

Shleifer, Andrei, and Robert Vishny, 1989. Management Entrenchment: The Case of Managerspecific Investments. Journal of Financial Economics 25, pp. 123-140.

Shleifer, A., and Vishny, R., 1997. A survey of corporate governance. Journal of Finance, 52, 737-775.

The UN Global Compact-Accenture CEO Study on Sustainability 2013 (Accessed at http://www.accenture.com/SiteCollectionDocuments/PDF/Accenture-UN-Global-Compact-AcnCEO-Study-Sustainability-2013.pdf on May 9, 2015)

Waddock, S.A. and S. Graves, 1997, The corporate social performance-financial performance link, Strategic Management Journal 18, 303-319.

Wade, J., C. A. O'Reilly and I. Chandratat, 1990. Golden parachutes: CEOs and the exercise of social influence, Administrative Science Quarterly, 35, pp. 587-603.

Walls, J. L., Berrone, P., \& Phan, P. H. 2012. Corporate governance and environmental performance: is there really a link?. Strategic Management Journal, 33(8), 885-913.

U.S. Senate, 2002, The Role of the Board of Directors in Enron's Collapse, Hearing before the Permanent Subcommittee of Investigations of the Committee on Governmental Affairs, S. Hrg. 107-511, Washington, D.C., Government Printing Office.

Salancik, G., 1977. Commitment and control of organizational behavior and belief. In: Staw, B.M., Salacnik, G.R. (Eds.), New directions in organizational behavior. St. Claire Press, Chicago, pp. 154 .

Vafeas, N, 2003, Length of Board Tenure and Outside Director Independence, Journal of Business Finance and Accounting, 30(7/8), 1043-1064.

Vance, S., 1983. Corporate Leadership: Boards, Directors and Strategy. McGraw-Hill, New York.

Yermack D., 1997, Good timing: CEO stock option awards and company news announcements, Journal of Finance, 52 (2), 449-476

Zeckhauser, R. and J. Pound. 1990. Are Large Shareholders Effective Monitors? An Investigation of Share Ownership and Corporate Performance' in R. Hubbard (ed.), Asymmetric Information, Corporate Finance, and Investment (University of Chicago Press), pp.149-180. 
Table 1. Descriptive statistics

\begin{tabular}{lcccccr}
\multicolumn{1}{c}{ Variable } & N & Mean & Median & Std Dev & Minimum & Maximum \\
CSRCONTRACTING & 2561 & 0.38 & 0.00 & 0.31 & 0.00 & 1 \\
AVG TENURE & 2561 & 8.81 & 8.80 & 3.12 & 0.40 & 23.00 \\
\% HIREBEFORE & 2561 & 0.04 & 0.00 & 0.20 & 0.00 & 1 \\
BOARDIND & 2355 & 0.82 & 0.86 & 0.10 & 0.40 & 1 \\
NUMBLOCKS & 1623 & 1.89 & 2.00 & 1.47 & 0.00 & 6 \\
SHROWN & 1841 & 1.04 & 0.14 & 2.93 & 0.00 & 25.22 \\
EXECDIR & 1736 & 0.31 & 0.00 & 0.46 & 0.00 & 1.00 \\
ROA & 2561 & 0.11 & 0.10 & 0.08 & -0.16 & 0.63 \\
LOGSALES & 2561 & 8.97 & 8.95 & 1.58 & 0.00 & 13.01 \\
CSRLEVEL & 2561 & 3.07 & 3.00 & 3.17 & -3.00 & 16.00 \\
BOOKLEVERAGE & 2561 & 0.17 & 0.12 & 0.19 & 0.00 & 1.56 \\
R\&D & 2561 & 0.01 & 0.00 & 0.04 & 0.00 & 0.40 \\
AD & 2561 & 0.01 & 0.00 & 0.02 & 0.00 & 0.24 \\
CEO & 2561 & 0.15 & 0.00 & 0.35 & 0.00 & 1
\end{tabular}




\section{Table 2. Univariate T-test}

This table reports the differences in means (T-statistics) between CSR-contracting firms and firms without CSR contracting. ${ }^{* *}, * *, *$ denote statistical significance at the $1 \%, 5 \%$, and $10 \%$ levels, respectively.

$\begin{array}{lccc}\text { AVG TENURE } & 9.09 & 8.31 & 2.78^{* * *} \\ \text { \% HIREBEFORE } & 0.04 & 0.04 & 1.02 \\ \text { BOARDIND } & 0.81 & 0.85 & 8.52^{* * *} \\ \text { NUMBLOCKS } & 1.92 & 1.83 & 1.20 \\ \text { SHROWN } & 1.22 & 0.72 & 3.46^{* * *} \\ \text { EXECDIR } & 0.32 & 0.28 & 1.61^{*} \\ \text { ROA } & 0.12 & 0.10 & 5.08^{* * *} \\ \text { LOGSALES } & 8.85 & 9.17 & 4.91^{* * *} \\ \text { CSRLEVEL } & 2.86 & 3.42 & 4.33^{* * *} \\ \text { BOOKLEVERAGE } & 0.17 & 0.16 & 1.16 \\ \text { R\&D } & 0.014 & 0.013 & 0.34 \\ \text { AD } & 0.009 & 0.006 & 2.73^{* * *} \\ & & & \\ \text { Number Of Firms } & 283 & 168 & \end{array}$




\section{Table 3. Correlation Table}

This table reports correlations between key variables that we use in our paper. The first line reports the Pearson correlation coefficients, the second line denotes the Probability $>|\mathrm{r}|$ under H0: Rho=0.

\begin{tabular}{|c|c|c|c|c|c|c|c|c|c|c|c|c|}
\hline & $\begin{array}{c}\text { CSRCONTR } \\
\text { ACTING }\end{array}$ & BOARDIND & NUMBLOCKS & SHROWN & EXECDIR & ROA & LOGSALES & CSRLEVEL & $\begin{array}{l}\text { BOOKLEV } \\
\text { ERAGE }\end{array}$ & R\&D & AD & CEO \\
\hline \multirow{2}{*}{$\begin{array}{c}\text { CSRCONTR } \\
\text { ACTING }\end{array}$} & 1 & 0.17 & -0.03 & -0.08 & -0.04 & -0.1 & 0.1 & 0.09 & -0.02 & -0.01 & -0.05 & -0.01 \\
\hline & & $<.0001$ & 0.2346 & 0.0006 & 0.1124 & $<.0001$ & $<.0001$ & $<.0001$ & 0.2455 & 0.736 & 0.0064 & 0.5511 \\
\hline \multirow[t]{2}{*}{ BOARDIND } & 0.17 & 1 & -0.01269 & -0.1823 & -0.09657 & -0.1417 & 0.15985 & 0.13472 & -0.04884 & -0.01575 & -0.14516 & -0.01825 \\
\hline & $<.0001$ & & 0.6112 & $<.0001$ & $<.0001$ & $<.0001$ & $<.0001$ & $<.0001$ & 0.0178 & 0.4449 & $<.0001$ & 0.376 \\
\hline \multirow[t]{2}{*}{ NUMBLOCKS } & -0.03 & -0.01269 & 1 & -0.08801 & -0.0432 & -0.04742 & -0.47121 & -0.11004 & 0.18696 & 0.10556 & -0.09398 & -0.00057 \\
\hline & 0.2346 & 0.6112 & & 0.0017 & 0.0819 & 0.0561 & $<.0001$ & $<.0001$ & $<.0001$ & $<.0001$ & 0.0001 & 0.9816 \\
\hline \multirow[t]{2}{*}{ SHROWN } & -0.08 & -0.1823 & -0.08801 & 1 & 0.06151 & -0.00853 & 0.02132 & -0.09117 & -0.01913 & 0.0106 & 0.03118 & 0.01498 \\
\hline & 0.0006 & $<.0001$ & 0.0017 & & 0.0234 & 0.7146 & 0.3606 & $<.0001$ & 0.4121 & 0.6495 & 0.1812 & 0.5207 \\
\hline \multirow[t]{2}{*}{ EXECDIR } & -0.04 & -0.09657 & -0.0432 & 0.06151 & 1 & 0.00549 & 0.02722 & -0.02583 & -0.01556 & -0.01477 & 0.02687 & 0.75214 \\
\hline & 0.1124 & $<.0001$ & 0.0819 & 0.0234 & & 0.8193 & 0.257 & 0.2821 & 0.5172 & 0.5387 & 0.2632 & $<.0001$ \\
\hline \multirow[t]{2}{*}{ ROA } & -0.1 & -0.1417 & -0.04742 & -0.00853 & 0.00549 & 1 & 0.0564 & -0.01364 & 0.02975 & 0.09366 & 0.29048 & 0.02297 \\
\hline & $<.0001$ & $<.0001$ & 0.0561 & 0.7146 & 0.8193 & & 0.0043 & 0.4902 & 0.1323 & $<.0001$ & $<.0001$ & 0.2451 \\
\hline \multirow[t]{2}{*}{ LOGSALES } & 0.1 & 0.15985 & -0.47121 & 0.02132 & 0.02722 & 0.0564 & 1 & 0.29948 & 0.05089 & -0.04697 & 0.02615 & 0.04153 \\
\hline & $<.0001$ & $<.0001$ & $<.0001$ & 0.3606 & 0.257 & 0.0043 & & $<.0001$ & 0.01 & 0.0175 & 0.1859 & 0.0356 \\
\hline \multirow{2}{*}{ CSRLEVEL } & 0.09 & 0.13472 & -0.11004 & -0.09117 & -0.02583 & -0.01364 & 0.29948 & 1 & 0.05967 & 0.12092 & 0.03438 & 0.0066 \\
\hline & $<.0001$ & $<.0001$ & $<.0001$ & $<.0001$ & 0.2821 & 0.4902 & $<.0001$ & & 0.0025 & $<.0001$ & 0.0819 & 0.7387 \\
\hline \multirow{2}{*}{$\begin{array}{l}\text { BOOKLEVE } \\
\text { RAGE }\end{array}$} & -0.02 & -0.04884 & 0.18696 & -0.01913 & -0.01556 & 0.02975 & 0.05089 & 0.05967 & 1 & 0.04549 & 0.18454 & 0.18283 \\
\hline & 0.2455 & 0.0178 & $<.0001$ & 0.4121 & 0.5172 & 0.1323 & 0.01 & 0.0025 & & 0.0213 & $<.0001$ & $<.0001$ \\
\hline \multirow[t]{2}{*}{ R\&D } & -0.01 & -0.01575 & 0.10556 & 0.0106 & -0.01477 & 0.09366 & -0.04697 & 0.12092 & 0.04549 & 1 & 0.06005 & 0.06244 \\
\hline & 0.736 & 0.4449 & $<.0001$ & 0.6495 & 0.5387 & $<.0001$ & 0.0175 & $<.0001$ & 0.0213 & & 0.0024 & 0.0016 \\
\hline \multirow[t]{2}{*}{ AD } & -0.05 & -0.14516 & -0.09398 & 0.03118 & 0.02687 & 0.29048 & 0.02615 & 0.03438 & 0.18454 & 0.06005 & 1 & 0.07668 \\
\hline & 0.0064 & $<.0001$ & 0.0001 & 0.1812 & 0.2632 & $<.0001$ & 0.1859 & 0.0819 & $<.0001$ & 0.0024 & & 0.0001 \\
\hline \multirow[t]{2}{*}{ CEO } & -0.01 & -0.01825 & -0.00057 & 0.01498 & 0.75214 & 0.02297 & 0.04153 & 0.0066 & 0.18283 & 0.06244 & 0.07668 & 1 \\
\hline & 0.5511 & 0.376 & 0.9816 & 0.5207 & $<.0001$ & 0.2451 & 0.0356 & 0.7387 & $<.0001$ & 0.0016 & 0.0001 & \\
\hline
\end{tabular}




\section{Table 4. CSR Contracting and Corporate Governance}

Results are from logistic regression models. The dependent variable is CSRCONTRACTING. Standard errors are clustered by firm, and are reported in parentheses. ***, **, * are statistically significant at the $1 \%, 5 \%$, and $10 \%$ levels, respectively.

\begin{tabular}{|c|c|c|c|c|c|c|c|c|}
\hline & (1) & (2) & (3) & (4) & (5) & (6) & (7) & (8) \\
\hline \multirow[t]{2}{*}{ AVG TENURE } & $-0.07 * * *$ & $-0.07 * * *$ & & & & & $-0.07 * * *$ & $-0.07 * * *$ \\
\hline & $(0.02)$ & $(0.02)$ & & & & & $(0.03)$ & $(0.03)$ \\
\hline \multirow[t]{2}{*}{ \% HIREBEFORE } & & & $0.55^{* * *}$ & $0.59 * * *$ & & & $0.53^{* * *}$ & $0.55^{* * *}$ \\
\hline & & & $(0.21)$ & $(0.21)$ & & & $(0.20)$ & $(0.20)$ \\
\hline \multirow[t]{2}{*}{ NUMBLOCKS } & & & & & $0.07 * * *$ & $0.08^{* * *}$ & $0.07 * *$ & $0.06^{* *}$ \\
\hline & & & & & $(0.02)$ & $(0.03)$ & $(0.03)$ & $(0.03)$ \\
\hline \multirow[t]{2}{*}{ CSRLEVEL } & & $0.08^{* * *}$ & & $0.08^{* * *}$ & & $0.02 *$ & & $0.02 * *$ \\
\hline & & $(0.02)$ & & $(0.02)$ & & $(0.01)$ & & $(0.01)$ \\
\hline \multirow[t]{2}{*}{ BOOKLEVERAGE } & & -0.37 & & -0.37 & & -0.33 & & -0.26 \\
\hline & & $(0.30)$ & & $(0.30)$ & & $(0.24)$ & & $(0.28)$ \\
\hline \multirow[t]{2}{*}{$\mathrm{R} \& \mathrm{D}$} & & 1.55 & & 1.34 & & $2.90 * * *$ & & $3.73 * * *$ \\
\hline & & $(1.23)$ & & $(1.37)$ & & $(1.11)$ & & (1.13) \\
\hline \multirow[t]{2}{*}{$\mathrm{AD}$} & & $4.91 * *$ & & $5.29 * *$ & & $3.83^{* *}$ & & $3.95^{* *}$ \\
\hline & & $(2.21)$ & & $(2.37)$ & & $(1.60)$ & & (1.65) \\
\hline \multirow[t]{2}{*}{ CEO } & & 0.02 & & 0.20 & & 0.03 & & 0.03 \\
\hline & & $(0.13)$ & & $(0.15)$ & & $(0.14)$ & & $(0.10)$ \\
\hline \multirow[t]{2}{*}{ ROA } & -0.60 & -0.81 & -0.49 & -0.79 & 0.47 & -0.55 & -0.56 & $-0.84 *$ \\
\hline & $(0.74)$ & $(0.77)$ & $(0.74)$ & $(0.77)$ & $(0.53)$ & $(0.41)$ & $(0.48)$ & $(0.44)$ \\
\hline \multirow[t]{2}{*}{ LOGSALES } & $0.34 * * *$ & $0.30 * * *$ & $0.34 * * *$ & $0.30^{* * *}$ & $0.26^{* * *}$ & $0.25^{* * *}$ & $0.25^{* * *}$ & $0.25^{* * *}$ \\
\hline & $(0.04)$ & $(0.05)$ & $(0.04)$ & $(0.05)$ & $(0.04)$ & $(0.04)$ & $(0.05)$ & $(0.04)$ \\
\hline \multirow[t]{2}{*}{ Intercept } & -4.22 & -4.01 & -4.03 & -3.83 & -2.46 & -2.87 & -3.81 & -4.20 \\
\hline & $(45.60)$ & (45.59) & (64.05) & $(64.02)$ & (35.02) & (34.84) & $(36.41)$ & (38.24) \\
\hline FF48 Industry & Yes & Yes & Yes & Yes & Yes & Yes & Yes & Yes \\
\hline Obs & 2561 & 2561 & 2098 & 2098 & 1623 & 1623 & 1606 & 1606 \\
\hline $\mathrm{R}^{2}$ & 0.21 & 0.22 & 0.20 & 0.22 & 0.25 & 0.26 & 0.26 & 0.27 \\
\hline
\end{tabular}




\section{Table 5. CSR Contracting and Managerial Power}

Results are from logistic regression models. The dependent variable is CSRCONTRACTING. Standard errors are clustered by firm, and are reported in parentheses. ***, **, * are statistically significant at the $1 \%, 5 \%$, and $10 \%$ levels, respectively.
(1)
(2)
(3)
(4)
(5)
(6)

SHROWN

$$
\begin{array}{ll}
-0.03^{* * *} & -0.03^{* * *} \\
(0.01) & (0.01)
\end{array}
$$

$-0.04 * * \quad-0.05 * * *$

(0.01) (0.02)

EXECDIR

CSRLEVEL

$-0.19$

$-0.21 *$

$-0.08$

$-0.23$

(0.11)

$(0.12)$

(0.08)

(0.14)

BOOKLEVERAGE

R\&D

AD

CEO

ROA

LOGSALES

Intercept

FF48 Industry

Obs

$\mathrm{R}^{2}$
$0.05^{* * *}$

(0.01)

0.24

(0.32)

$7.71^{* * *}$

(1.59)

$$
5.68^{* * *}
$$

(1.71)

0.05

(0.10)

0.05
$(0.10)$

$-1.60 * * * \quad-2.33^{* * *}$

(0.50)

(0.54)

$-0.83$

(0.53)

$0.05^{* * *}$

(0.01)

$-0.45$

(0.25)

$3.34^{* * *}$

(1.11)

$3.36 * *$

(1.63)

0.20

(0.13)

$0.22^{* * *}$

$0.11^{* * *}$

$0.20 * * *$

(0.03)

(0.03)

(0.03)

$-0.97 *$

(0.55)

$-0.86$

(0.65)

(0.73)

$0.20 * * *$

(0.04)

$0.23^{* * *}$

(0.04)

$0.21^{* * *}$

(0.04)

\section{$-2.59$}

(37.28)

$-4.08$

(39.03)

$-2.89$

$-2.90$

(33.92)

(34.81)

$-3.01$

$-4.29$

Yes

Yes

Yes

Yes

(38.00)

(39.02)

1824

1288

0.30

1736

1632

0.25

0.25

Yes

Yes

0.22

1358

1288

$0.28 \quad 0.31$

(0.02)

0.21

(0.33)

(1.62)

$5.43^{* * *}$

(1.78)

0.26

(0.18)

$-1.68^{* *}$
$8.02 * * *$ 


\section{Table 6. CSR Contracting and CSR Level}

Results are from ordinary least squares (OLS) regression models. The dependent variable is CSRLEVEL in 2013, with CSRLEVEL2012 denoting the value of CSRLEVEL in 2012. Standard errors are clustered by firm, and are reported in parentheses. $* * *, * *, *$ are statistically significant at the $1 \%, 5 \%$, and $10 \%$ levels, respectively.

(1) (2) (3)

$\begin{array}{llll}\text { CSRCONTRACTING } & 0.66^{* * *} & 0.54^{* *} & 0.56^{* *} \\ & (0.23) & (0.24) & (0.24) \\ \text { CSRLEVEL2012 } & 0.83^{* * *} & 0.83^{* * *} & 0.84^{* * *} \\ & (0.04) & (0.04) & (0.04) \\ \text { BOOKLEVERAGE } & 2.40^{* *} & & 4.13^{* *} \\ & (1.08) & & (1.73) \\ \text { R\&D } & 5.13 & & 5.51 \\ & (3.51) & & (4.99) \\ \text { AD } & 2.67 & & -3.29 \\ & (4.60) & & (5.34) \\ \text { ROA } & -0.15 & -0.90 & -0.79 \\ & (1.40) & (1.43) & (1.47) \\ \text { LOGSALES } & 0.16^{* *} & 0.15^{* *} & 0.16^{* *} \\ & (0.08) & (0.08) & (0.08) \\ \text { R } & & & \\ \text { Intercept } & -0.35 & -4.2 & -3.58^{* *} \\ & (0.69) & (2.33) & (1.54) \\ \text { FF48 Industry } & \text { No } & \text { Yes } & \text { Yes } \\ & & & \\ & 451 & 451 & 451 \\ & 0.59 & 0.67 & 0.67 \\ & & & \end{array}$




\section{Appendix 1. Variable Definitions}

\begin{tabular}{ll}
\hline Variable & Definition \\
\hline CSR & \\
\hline CSRCONTRACTING & $\begin{array}{l}\text { A dummy variable }=1 \text { if an executive's compensation contract has a CSR-related } \\
\text { incentive component and } 0 \text { otherwise. }\end{array}$ \\
CSRLEVEL & $\begin{array}{l}\text { KLD scores (total strengths minus total concerns) aggregated across the categories of } \\
\text { community, diversity, employee relations, environment, human rights, and product. }\end{array}$
\end{tabular}

\section{Executive Characteristics}

EXECDIR A dummy variable $=1$ if an executive is also a board member and 0 otherwise.

SHROWN The number of shares owned by the executive divided by the company's total shares outstanding

CEO A dummy variable $=1$ if executive is the CEO of the firm for the majority of the fiscal year and 0 if not.

\section{Governance Characteristics}

AVG TENURE $\quad$ The average number of years the directors have been serving in the board.

\% HIREBEFORE The percentage of board members hired before the CEO.

NUMBLOCKS The number of block shareholders, where a block exists if an institution holds more than $5 \%$ of the firm's outstanding voting equity.

\section{Firm characteristics}

R\&D Total research and development expenses divided by total sales.

AD Total advertising expenses divided by total sales.

BOOKLEVERAGE Book leverage: Interest-bearing debt divided by total assets.

LOGSALES The natural logarithm of total sales.

ROA Return on assets: Net income before extraordinary items and discontinued operations divided by total assets. 


\section{Appendix 2. CSR Compensation Terms}

Based on an analysis of variable and performance-based pay, we identified those companies also incentivizing non-financial performance. We then analyzed the descriptions of non-financial performance to code the compensation as CSR-linked. The following were the most common such descriptions:

- Community

- Compliance with ethical standards

- Corporate social responsibility

- Diversity

- Employee well-being

- Energy efficiency

- Environmental compliance

- Environmental goals

- Environmental performance

- Environmental projects

- Greenhouse gas emissions reductions

- Health

- Performance relative to a corporate responsibility index (e.g., Dow Jones Sustainability Index)

- Product safety

- Reduced injury rates

- Safety

- Sustainability

For example, as discussed in its Proxy Statement, the Kellogg Company divided its Annual Incentive Plan for its CEO John Bryant into financial and non-financial incentives: "90\% of the annual incentive opportunity was based on performance against corporate financial metrics...and $10 \%$ was based on performance against non-financial targets (people safety, food safety and quality, and diversity and inclusion).” Thus, John Bryant of Kellogg is coded as being offered CSR-linked incentives.

The compensation plans typically contract on a dimension of social performance with symmetric consequences. For example, one common area of contracting is Employee Diversity and Inclusion. In 
principle, a CEO could be credited for doing well, poorly or both well and poorly on this dimension. For an example of the latter, the firm may experience an increase in promotions for women but a reduction in promotions for minorities. In this setting, the CEO's compensation would be based on the net results of these "strengths" and "concerns." Additionally, the CSR performance compensation payment is usually based on the net result of "strengths" and "concerns" across multiple categories. Hence, it could be that a given category of CSR compensation contains only "strengths” or "concerns." Nonetheless, the final payment to the CEO is based on the net result of all of the categories, which mirrors our empirical analysis. 